\title{
HUBUNGAN ANTARA LAMANYA MENJALANI HEMODIALISIS DENGAN TINGKAT KECEMASAN PADA PASIEN DENGAN PENYAKIT GINJAL KRONIK DI RSUP PROF. Dr. R. D. KANDOU MANADO
}

\author{
${ }^{1}$ Befly F. Tokala \\ ${ }^{2}$ Lisbeth F. J. Kandou \\ ${ }^{2}$ Anita E. Dundu \\ ${ }^{1}$ Kandidat Skripsi Fakultas Kedokteran Universitas Sam Ratulangi Manado \\ ${ }^{2}$ Bagian Psikiatri Fakultas Kedokteran Universitas Sam Ratulangi Manado \\ Email: bftokala11_169@yahoo.co.id
}

\begin{abstract}
The incidence of chronic kidney disease (CKD) has increased. Efforts are being made to deal with this problem by using hemodialysis. CKD patients undergo hemodialysis for years. This can result in disorders such as anxiety. This study aimed to obtain the relationship between the duration of hemodialysis and levels of anxiety in patients with CKD in hemodialysis unit at Prof. Dr. R. D. Kandou Hospital, Manado. This was an observational analytical study using cross sectional approach. Data were socio-demographic status and the HARS questionnaire which were processed by using SPSS 20. From a total of 34 respondents, 18 people (52.9\%) experienced varying degrees of anxiety. The Spearman test resulted in $\mathrm{p}=$ $0.462>0.05$ which meant that there was no relationship between the duration of hemodialysis and levels of anxiety in patients with CKD. Conclusion: There was no relationship between the duration of hemodialysis and levels of anxiety in patients with CKD in hemodialysis unit, however, there were some respondents who experienced anxiety.
\end{abstract}

Keywords: anxiety, hemodialysis, CKD

\begin{abstract}
Abstrak: Kejadian Penyakit ginjal kronik (PGK) semakin meningkat. Upaya yang dilakukan untuk menangani masalah ini salah satunya dengan hemodialisis. Pasien PGK membutuhkan waktu bertahun - tahun untuk menjalani hemodialisis. Hal ini dapat mengakibatkan gangguan psikologi seperti kecemasan. Penelitian ini bertujuan untuk mengetahui hubungan antara lamanya menjalani hemodialisis dengan tingkat kecemasan pada pasien PGK di unit hemodialisis RSUP Prof. R. D. Kandou Manado. Penelitian ini bersifat observasional analitik dengan pendekatan potong lintang. Data dikumpulkan melalui pengisian data sosiodemografi dan wawancara dengan kuesioner HARS kemudian diolah dengan SPSS 20. Dari total 34 responden, ditemukan 18 orang (52,9\%) mengalami kecemasan dengan derajat yang berbedabeda, akan tetapi pada uji Spearman menunjukan hasil $\mathrm{p}=0$ 0,462 yaitu $>0,05$ yang artinya tidak terdapat hubungan antara lamanya menjalani hemodialisis dengan tingkat kecemasan pada pasien dengan PGK. Simpulan: Tidak terdapat hubungan antara lamanya menjalani hemodialisis dengan tingkat kecemasan pada pasien PGK di unit hemodialisis, walaupun demikian terdapat sebagian responden yang mengalami cemas.
\end{abstract}

Kata kunci: kecemasan, hemodalisis, penyakit ginjal kronik

Penyakit ginjal kronik sudah merupakan masalah kesehatan masyarakat. ${ }^{1,2}$ Berbagai upaya dilakukan untuk mengatasi berbagai masalah penyakit ginjal kronik seperti mengatur pola makan (diet), dialisis dan transplantasi ginjal. Dialisis terbagi menjadi dua yaitu peritoneal dialisis dan hemodialisis. Metode pengobatan yang 
Tokala, Kandou, Dundu: Hubungan antara lamanya...

paling sering untuk penyakit ginjal kronis adalah hemodialisis. ${ }^{3,4}$ Menurut data dari Indonesian Renal Registry, pada tahun 2011 terdapat 15.353 pasien yang baru akan menjalani hemodialisis dan 6.951 pasien yang tercatat aktif menjalani hemodialisis, pada tahun 2012 terjadi peningkatan, pasien yang baru akan menjalani hemodialisis berjumlah 19.621 dan pasien yang aktif menjalani hemodialisis 9.161 orang. Kejadian ini meningkat berdasarkan jumlah pasien yang baru dan lama tercatat lebih banyak karena jumlah unit hemodialisis yang melaporkan pun meningkat. ${ }^{5}$

Pasien yang menjalani hemodialisis mengalami berbagai masalah yang timbul akibat tidak berfungsinya ginjal. Hal ini menjadi stresor fisik yang berpengaruh pada berbagai dimensi kehidupan pasien yang meliputi biologi, psikologi, sosial, spiritual (biopsikososial). Kelemahan fisik yang dirasakan seperti mual, muntah, nyeri, lemah otot dan edema merupakan sebagian dari manifestasi klinik dari pasien yang menjalani HD. ${ }^{6}$ Pasien yang menjalani dialisis mungkin mengalami kurangnya kontrol atas aktivitas kehidupan sehari-hari dan sosial, kehilangan kebebasan, pensiun dini, tekanan keuangan, gangguan dalam kehidupan keluarga, perubahan citra diri, dan berkurang harga diri. Hal ini mengakibatkan masalah dalam psikososial, seperti kecemasan, depresi, isolasi sosial, kesepian, tidak berdaya, dan putus asa. ${ }^{7}$ Berdasarkan penelitian Tanvir dkk di Pakistan, 65,9\% pasien dengan penyakit ginjal kronik yang dihemodialsis mengalami kecemasan dan depresi. ${ }^{8}$ Pada penelitian yang pernah di lakukan di Rumah Sakit Universitas Kristen Indonesia pada tahun 2012 di temukan tingkat derajat kecemasan yang berbeda-beda pada pasien yang menjalani terapi hemodialisis. ${ }^{4}$ Berdasarkan uraian tersebut peneliti tertarik untuk melakukan penelitian mengenai hubungan antara lamanya menjalani Hemodialisis dengan tingkat kecemasan pada pasien Penyakit Ginjal Kronik di unit hemodialisis RSUP Prof. R. D. Kandou Manado.

\section{KECEMASAN}

Kecemasan menurut Kaplan, Sadock dan Grebb adalah suatu sinyal yang menyadarkan, memperingatkan adanya bahaya yang mengancam dan memungkinkan seseorang mengambil tindakan untuk mengatasi ancaman. Kecemasan memperingatkan adanya ancaman eksternal dan internal; dan memiliki kualitas menyelamatkan hidup. ${ }^{9}$

1. Tingkat Kecemasan ${ }^{10}$

Menurut Townsend, tingkat kecemasan dibagi atas :

a. Kecemasan Ringan: Berhubungan dengan ketegangan dalam kehidupan sehari-hari, kecemasan ini menyebabkan seseorang menjadi waspada.

b. Kecemasan Sedang: Manifestasi yang muncul kelelahan, denyut jantung, pernapasan dan ketegangan otot meningkat, bicara cepat dengan volume tinggi, mampu untuk belajar namun tidak terfokus pada rangsang yang tidak menambah kecemasan, mudah tersinggung, mudah lupa, marah dan menangis.

c. Kecemasan Berat: Manifestasi yang timbul seperti mengeluh pusing, sakit kepala, mual, tidak dapat tidur (insomnia), sering kencing, diare, palpitasi, tidak mau belajar secara efektif, berfokus pada dirinya sendiri, tidak berdaya, bingung dan mengalami disorientasi.

d. Panik: Tidak mampu melakukan sesuatu walaupun dengan pengarahan tanda dan gejala yang di alami seperti susah bernafas, dilatasi pupil, palpitasi, pucat, diaphoresis, pembicaraan inkoheren, tidak dapat berespon terhadap perintah yang sederhana, berteriak-teriak, menjerit, mengalami halusinasi dan delusi, dan mengakibatkan peningkatan motorik, penurunan kemampuan berhubungan dengan orang lain dan tidak mampu berpikir rasional.

\section{HEMODIALISIS}

Hemodialisis (HD) adalah suatu prosedur dimana darah dikeluarkan dari tubuh penderita dan beredar dalam sebuah 
mesin diluar tubuh yang disebut dialiser. ${ }^{11}$ Hemodialisis menggunakan prinsip-prinsip difusi zat terlarut menembus membrane semipermeabel. Perpindahan produk sisa metabolik berlangsung mengikuti penurunan gradien konsentrasi dari sirkulasi ke dalam dialisat. $^{12}$ Indikasi dialisis pada Penyakit Ginjal Kronik adalah bila laju filtrasi glomerulus (LFG) sudah kurang dari $5 \mathrm{~mL} / \mathrm{menit}$. Dialisis di anggap baru perlu di mulai bila di jumpai salah satu dari hal berikut: Keadaan umum buruk dan gejala klinis nyata, $\mathrm{K}$ serum $>6$ $\mathrm{mEq} / \mathrm{L}$, Ureum darah $>200 \mathrm{mg} / \mathrm{L}, \mathrm{pH}$ darah $<7,1$, Anuria berkepanjangan ( $>5$ hari), dan fluid overloaded atau hipervolemia

\section{HUBUNGAN KECEMASAN DENGAN PENYAKIT GINJAL KRONIK}

Menurut Smeltzer, seperti yang dikutip Yunita dalam jurnal Hubungan tingkat stress dan strategi koping pada pasien yang menjalani terapi hemodialisa, pasien penyakit ginjal kronik yang menjalani hemodialisis sering mengalami masalah baik biologis maupun masalah psikososial yang muncul dalam kehidupan. ${ }^{13}$ Akibatnya, mereka juga mengalami masalah psikososial, seperti kecemasan, depresi, isolasi sosial, kesepian, tidak berdaya, dan putus asa. ${ }^{7}$

\section{METODE PENELITIAN}

Penelitian ini menggunakan desain penelitian observasional analitik dengan pendekatan potong lintang. Penelitian ini di lakukan pada dua unit Hemodialisis RSUP Prof. dr. R. D. Kandou Manado, Sulawesi Utara. Populasi penelitian yaitu pasien yang menjalani hemodialisis di dua unit hemodialisis RSUP Prof. dr. R. D. Kandou Manado. Cara pengambilan sampel secara purposive sampling.

Kriteria Inklusi pada penelitian ini adalah pasien yang sedang menjalani terapi hemodialisis, pasien yang sudah menikah dan memiliki pasangan hidup sah yang datang bersama pasangan, berumur $<60$ tahun. Penelitian ini menggunakan kuesioner Hamilton Anxiety Rating Scale
(HARS) untuk menilai tingkat kecemasan responden.

\section{HASIL PENELITIAN}

\section{Jenis Kelamin}

Tabel 1. Distribusi Responden Menurut Kategori Jenis Kelamin

\begin{tabular}{llc}
\hline Jenis Kelamin & $\mathrm{n}$ & $(\%)$ \\
\hline Laki - laki & 30 & 88,2 \\
Perempuan & 4 & 11,8 \\
Total & 34 & 100 \\
\hline
\end{tabular}

Tabel 1 menunjukkan bahwa responden terbanyak ialah laki-laki sebanyak 30 orang $(88,2 \%)$ sedangkan perempuan 4 orang $(11,8 \%)$.

\section{Umur}

Tabel 2. Distribusi Responden Menurut Kategori Umur

\begin{tabular}{lll}
\hline Umur & $\mathrm{n}$ & $\mathbf{( \% )}$ \\
\hline $26-35$ tahun & 4 & 11,8 \\
$36-45$ tahun & 10 & 29,4 \\
46-55 tahun & 11 & 32,4 \\
56-65 tahun & 9 & 26,5 \\
Total & 34 & 100 \\
\hline
\end{tabular}

Tabel 2 menunjukkan responden dalam kategori umur 46-55 tahun sebanyak 11 orang $(32,4 \%)$ yang paling sedikit dalam kategori 26-35 tahun yaitu 4 orang $(11,8 \%)$.

\section{Lama Menjalani Hemodialisis}

Tabel 3. Distribusi Responden Berdasarkan Lamanya Menjalani Hemodialisis

\begin{tabular}{lll}
\hline Lama HD & $\mathrm{n}$ & $(\%)$ \\
\hline$\leq 6$ bulan & 15 & 44,1 \\
$>6$ bulan & 19 & 55,9 \\
Total & 34 & 100 \\
\hline
\end{tabular}

Tabel 3 menunjukan bahwa responden yang menjalani hemodialisis $\leq 6$ bulan sebanyak 15 orang $(44,1 \%)$ dan $>6$ bulan sebanyak 19 orang $(55,9 \%)$. 


\section{Tingkat Kecemasan}

Tabel 4. Distribusi Responden Berdasarkan Tingkat Kecemasan

\begin{tabular}{|c|c|c|}
\hline Tingkat Kecemasan & $\mathrm{n}$ & $(\%)$ \\
\hline Tidak ada & 16 & 47,1 \\
\hline Ringan & 11 & 32,4 \\
\hline Sedang & 6 & 17,6 \\
\hline Berat & 1 & 2,9 \\
\hline Berat Sekali & 0 & 0 \\
\hline Total & & 100 \\
\hline
\end{tabular}

Tabel 4 menunjukkan responden yang terbanyak adalah responden tanpa kecemasan sebanyak 16 orang $(47,1 \%)$ dan yang paling sedikit responden dengan kecemasan berat yaitu 1 orang (2,9\%).

\section{Hasil analisis bivariat hubungan antara tingkat lamanya menjalani hemodialisis dengan tingkat kecemasan}

Pada Tabel 5, berdasarkan analisis bivariat dengan menggunakan uji Spearman menunjukan hasil nilai uji $\mathrm{p}=$ 0,462 yaitu > 0,05 yang artinya tidak terdapat hubungan antara lamanya menjalani hemodialisis dengan tingkat kecemasan pada pasien dengan penyakit ginjal kronik.

Tabel 5. Hasil analisis bivariat

\begin{tabular}{ccc}
\hline Hubungan & r & p \\
\hline Lamanya Menjalani & & \\
Hemodialisis - & 0,130 & 0,462 \\
Tingkat Kecemasan & & \\
Berdasarkan HARS & & \\
\hline
\end{tabular}

\section{BAHASAN}

Berdasarkan hasil penelitian dan analisis univariat menurut karakteristik responden yang berjumlah 34 orang menunjukan jenis kelamin terbanyak yaitu laki - laki sebanyak 30 orang dan perempuan 4 orang. Jumlah pasien ini hampir sama pada penelitian yang di lakukan oleh Hannie dkk dalam Hubungan Umur dan Lamanya Hemodialisis dengan Status Gizi pada Penderita Penyakit Ginjal Kronik yang menjalani Hemodialisis di RS.
Dr. M. Djamil Padang yaitu jumlah lakilaki lebih banyak daripada perempuan yaitu laki-laki 36 orang dan perempuan 23 orang, ${ }^{14}$ begitu juga pada penelitian yang dilakukan oleh Anees yang menyatakan bahwa prevalensi laki-laki gagal ginjal kronik lebih banyak dua kali lipat dibandingkan dengan perempuan $(58,4 \%) .{ }^{15}$ Tingkat kecemasan berat yang di alami 1 orang responden laki-laki, menurut peneliti hal ini bergantung pada bagaimana cara pandang pasien terhadap penyakitnya, dukungan keluarga, lingkungan sosial pasien dan masalah yang di alami pasien. Menurut Gottlieb (1983) dalam Nursalam dan Dian (2007) yang di kutip oleh Romani dkk yang mengungkapkan bahwa dukungan sosial yang diberikan oleh lingkungan mempunyai manfaat emosional atau efek perilaku bagi pihak penerima. ${ }^{16}$

Hasil penelitian menurut umur responden yang terbanyak pada kategori umur 46-55 tahun sebanyak 11 orang dan yang paling sedikit pada kategori umur 2635 tahun. Hasil distribusi umur ini hampir sama dengan penelitian yang di lakukan Bertalina dkk yang memperoleh jumlah responden terbanyak dari umur 41-60 tahun keatas. $^{17}$ Pada responden yang termasuk dalam kategori umur 46-55 tahun, 1 orang responden mengalami kecemasan berat, hal ini berkaitan dengan bagaimana cara mengatasi masalah pasien. ${ }^{16}$

Berdasarkan tingkat kecemasan responden terdapat 18 orang (52,9\%) pasien mengalami cemas dengan derajat tingkat kecemasan berbeda-beda dan 16 orang $(47,1 \%)$ tidak mengalami kecemasan. Hal ini sesuai dengan penelitian Luana dkk dalam Kecemasan pada penderita penyakit ginjal kronik yang menjalani hemodialisis di RS Universitas Kristen Indonesia yang mengatakan bahwa tingkat kecemasan pada pasien hemodialisis dalam derajat yang berbedabeda. ${ }^{4}$ Menurut peneliti kecemasan merupakan suatu perasaan emosional, yang dapat membuat pasien merasa khawatir dan takut akan suatu hal. 


\section{Hubungan lamanya menjalani hemodialisis dengan tingkat kecemasan}

Berdasarkan hasil uji hipotesis menggunakan uji Spearman, menurut lamanya menjalani hemodialsis dengan tingkat kecemasan menunjukan bahwa tidak terdapat hubungan yang signifikan antara lamanya menjalani hemodiaisis dengan tingkat kecemasan. Tetapi berdasarkan penelitian ini, hemodialisis dapat juga mempengaruhi kecemasan pada pasien, sesuai hasil penelitian yang menunjukan sebanyak 52,9\% pasien hemodialisis mengalami kecemasan. Hal ini sesuai dengan teori yang menyatakan bahwa penyakit kronik sangat membuat tertekan dan dapat membuat pasien mengalami masalah psikologis. Dan pasien yang menjalani hemodialisis seharusnya mengalami masalah psikososial seperti kecemasan, depresi, isolasi sosial, kesepian, tidak berdaya dan putus asa akibat kurangnya kontrol atas aktivitas

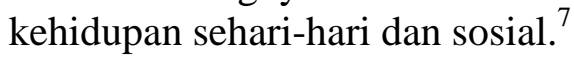

Dan pada penelitian ini didapatkan juga $47,1 \%$ tidak mengalami cemas. Hal ini terjadi karena dukungan keluarga dan bagaimana pasien menghadapi penyakit yang diderita, seperti penelitian Romani dkk dalam hubungan mekanisme koping individu dengan tingkat kecemasan pada pasien gagal ginjal kronis di unit hemodialisa RSUP. Dr. Soeradji Tirtonegoro Klaten yang mengatakan bahwa pasien yang mendapat dukungan dapat mengatasi kecemasan sehingga kecemasan yang dirasakan tidak berat. ${ }^{16}$

Kekurangan dari penelitian ini, hanya memperoleh sedikit sampel, ada perbedaan yang signifikan pada jumlah responden dalam kategori jenis kelamin. Penelitian ini hanya mendeskripsikan karakteristik responden terhadap kecemasan tanpa mencari adanya hubungan antara karakteristik responden dengan tingkat kecemasan pada pasien dengan penyakit ginjal kronik.

Penilaian skor berdasarkan HARS ini dapat menyebabkan bias (kesalahan) karena pada beberapa gejala yang ada merupakan proses alami penuaan dan beberapa poin pada HARS merupakan halhal yang sering terjadi pada pasien hemodialisis.

\section{SIMPULAN}

Tidak terdapat hubungan signifikan antara lama menjalani hemodialisis dengan tingkat kecemasan.

\section{SARAN}

Bagi peneliti selanjutnya mempertimbangkan metode penelitian lain dan mencari hubungan dengan faktor-faktor lain yang dinilai dapat merupakan penyebab kecemasan pada pasien.

\section{DAFTAR PUSTAKA}

1. Venkat A, Kaufmann KR, Venkat KK. Care of the end-stage renal disease patient on dialysis in the ED. American Journal of emergency medicine. 2006;24:847.

2. Butar-butar A, Siregar CT. Karateristik pasien dan kualitas hidup pasien gagal ginjal kronik yang menjalani terapi hemodialisa. Fakultas keperawatan Universitas Sumatera Utara. Jurnal USU. 2013.

3. Gerogianni SK, Babatsikou FP. Psycological aspect in chronic renal failure. Health science journal. 2014;8:206-14.

4. Luana NA, Panggabean S, Lengkong JVM, Christine I. Kecemasan pada penderita penyakit ginjal kronik yang menjalani hemodialisis di RS Universitas Kristen Indonesia. Media medika indonesiana. 2012;46:153

5. Anonim. Indonesian Renal Registry. $5^{\text {th }}$ report of Indonesian renal registry. Diakses pada tanggal 29 januari 2015, tersedia online di http://www.pernefriinasn.org/Laporan/5th\%20Annual\%2 0Report\%20Of\%20IRR\%202012.pdf

6. Ratnawati. Tingkat kecemasan pasien dengan tindakan hemodialisa di BLUD RSU dr. M. M. Dunda kabupaten Gorontalo. Jurnal health and sport. 2011;3:285-362.

7. Tezel A, Karabulutlu E, Sahin O. Depression and perceived social support from family in Turkish patients with chronic renal failure 
treated by hemodialysis. J Res Med Sci. 2011;16:666-73.

8. Tanvir S, Butt GD, Taj R. Prevalence of depression and anxiety in chronic kidney disease patients on hemodialysis. Ann Pakistan Instituse of Medical Sciences. 2013;9(2)64-67

9. Harold IK, Sadock BJ, Grebb JA. Sinopsis psikiatri. Jilid 2. Binarupa Aksara. 2010:3-4

10.Atina II, Winarsih NA. Hubungan tingkat kecemasan dengan mekanisme koping pada pasien gagal jantung kongestif di RSU Pandan Arang Boyolali. Berita ilmu keperawatan. 2008;1:164-5.

11.Supriyadi, Wagiyo, Widowati SR. Tingkat kualitas hidup pasien gagal ginjal kronik terapi hemodialisis. Jurnal kesehatan mayarakat. 2011;6:107-12.

12.Liu KD, Chertow GM. Dialisis dalam pengobatan gagal ginjal. Dalam : Jameson JL, Loscalzo J, editor. Harrison nefrologi dan gangguan asam-basa. EGC. 2013. p. 122.

13.Sari Y, Elita V, Novayelinda R. Hubungan tingkat stres dan strategi koping pada pasien yang menjalani terapi hemodialisa. Universitas Riau. Jurnal skripsi. 2011

14.Syaiful HQ, Oenzil F, Afriant R. Hubungan umur dan lamanya hemodialisis dengan status gizi pada penderita Penyakit Ginjal Kronik yang menjalani hemodialisis di RS. Dr. M. Djamil Padang. Jurnal Kesehatan Andalas. 20143(3):383-8.

15.Anees M, Barki $H$, Masood M, Ibrahim M, Mumtaz A. Depression in hemodialisis patients. Pak J Med Sci.2008;24(4):560-5.

16.Romani NK, Hendarsih S, Asmarani FL. Hubungan mekanisme koping individu dengan tingkat kecemasan pada pasien gagal ginjal kronis di unit hemodialisa RSUP. Dr. Soeradji Tirtonegoro Klaten. Medika respati. 2013;8(1):12.

17.Bertalina, Sumardilah DS. Faktor kepatuhan diet pasien gagal ginjal kronik yang menjalani hemodialisa. Jurusan Gizi Poltekkes Kemenkes Tanjungkarang. Jurnal kesehatan. 2012(2):150-8. 